\title{
Obituary: Stephan Leibfried
}

Marius R. Busemeyer (marius.busemeyer@uni-konstanz.de)

Universität Konstanz, Germany

The sudden passing of Stephan Leibfried in March of this year was a shocking event for his family, friends and colleagues and a deep loss for the German social science community. Stephan Leibfried has enormously enriched and contributed to this community not only through his research, but also through his unbroken and enthusiastic commitment to promoting social policy research in Germany and beyond. Since being appointed to a professorship for social policy and administration at a very young age, he remained loyal to the University of Bremen, contributing to turning the university into an internationally visible hub for social policy research. Stephan Leibfried was a perpetual source of ideas, a science manager and institution builder who left his imprint on renowned institutions such as the Zentrum für Sozialpolitik (ZeS, which is now integrated into the SOCIUM), the Bremen International School of Social Sciences (BIGSSS) and three (!) DFG Collaborative Research Centres. For many, the Collaborative Research Centre (CRC) on "Transformations of the State" (2003-2014) in particular, was closely affiliated with the name and person of Stephan Leibfried.

In his research, Stephan Leibfried covered an enormous variety of topics, which cannot all be addressed here. In any case, he had always been and continued to be "ahead of the curve". In his joint work with Paul Pierson in the 1990s, he explored the social policy dimension of European integration well before the side effects of asymmetrical economic integration had materialized. Collaborating with Jutta Allmendinger in the early 2000s, he pointed to the central role of education in the welfare state and how educational inequality can promote particular forms of "education poverty" with deleterious long-term consequences for social inclusion. The research program on "transformations of the state", of the above-mentioned CRC, reflected on the changing role of the state in a globalized world, in which the nation state as a historical and political construct is continuously and increasingly put under pressure.

Besides his contributions to research, I have always been extremely impressed with Stephan Leibfried's openness towards new and unconventional ideas and his continued engagement for young scholars, moving beyond Germanic conceptions of hierarchical chair structures and neatly separated "schools of thought". Stephan Leibfried has done a lot to promote the internationalization of German social science by collaborating with international top scholars early on and by building networks between German and international scholars, for instance when he was involved as a co-editor for two of the renowned Oxford handbooks. The Schader Foundation's life-time award for Stephan Leibfried in 2014 was a timely appreciation of this continued contribution to social science research. 
As somebody who does not belong to the inner circle of Bremen, I would like to take this opportunity to reflect on his wider contributions for social policy research in Germany as well as my personal experiences with him. A couple of years ago, I had the opportunity to work with him and a number of colleagues in the context of an initiative, which aimed at mobilizing additional resources for social policy research in Germany in order to counteract a perceived gradual erosion of fiscal conditions in this field. Even though the initial goal - to set up a dedicated fund at the DFG - was not achieved, the initiative was still successful in the end: In 2016, the Federal Ministry of Labour and Social Affairs (BMAS) set up the Research Network on Interdisciplinary Social Policy Research (Fördernetzwerk Interdisziplinäre Sozialpolitikforschung, FIS) to support the establishment of professorships, junior research groups and further projects at universities and higher education institutions. Without doubt, Stephan Leibfried's enthusiasm and dogged persistence as well as his excellent political networks at the Land and Federal level contributed to the eventual success of this initiative.

Taking a step back, our collaboration a couple of years ago was - as a first step - focused on writing a memorandum ("Denkschrift") on the state of social policy research in Germany. Besides demonstrating to policy-makers and sponsors the breadth and variety of social policy research in Germany and in neighboring countries, this memorandum had the positive side effect for the scientific community to engage in a process of selfreflection and stock-taking. Stephan Leibfried's engagement for this project was crucial, not only because we benefited enormously from his unrivalled knowledge of the field and his personal networks, but also because of his unbridled enthusiasm for the project, counterintuitively coupled with modesty, which I found very impressive: At first, Stephan Leibfried was not officially enlisted as co-editor of the edited volume that eventually came out of this project. Only after he had already negotiated a deal with a publisher and was probably about to start editing the extensive list of references, we - the remaining co-editors - found the presence of mind to ask him to become an official co-editor.

Unlike his colleagues in Bremen, I did not have the privilege of sharing everyday life at the University with Stephan Leibfried. I remember one particular instance, however, from our various meetings: Him steering an old Mercedes in winterly weather conditions with me in the front-seat and three further passengers in the back, discussing the most recent news in the social policy community while driving the car with one hand and freeing the windscreen of fog with the other. I also remember fondly the annual Christmas cards - which increasingly became large-sized posters - of different kinds of ships at sea and marked with hardly readable handwritten notes on the latest strategies to promote social policy research in Germany.

The gap that Stephan Leibfried's passing has opened up is large and very difficult to fill. For the young generation of social policy scholars, who now have to follow in his footsteps, and for me personally, he was a leading and inspiring scholar, both in terms of his research as well as his personality. We will deeply miss him. 